\title{
EXPLORING MOTHER'S HEALTHY FEEDING PRACTICES OF CHILDREN, AGES 4-6 YEARS: A QUALITATIVE STUDY
}

\author{
Anita Rahmiwati, ${ }^{1}$ Ditia Fitri Arinda, ${ }^{2}$ Feranita Utama, ${ }^{3}$ Misnaniarti ${ }^{4}$ \\ ${ }^{1-4}$ Faculty of Public Health, Sriwijaya University
}

\begin{abstract}
Background: Feeding or eating good upbringing which affects the development growth and intelligence of children. For that, it is necessary for feeding patterns or parenting eat right and balanced in order to stay healthy and avoid infection or other diseases related to nutrition. A balanced diet is eating according to the composition of food that our body needs in portions adapted to the needs of children at each age.

Methods: Respondents in this study are the parents of kindergarten children Rabbani North Indaralaya with a range of aged 4-6 years. Implementation of FGD was attended by 12 people, consisting; three researchers, two minutes, and seven respondents. Respondents selected through purposive sampling, based on predetermined criteria and is considered capable of answering research problems. The purpose of the study is to explore more deeply about parenting feeding mothers in Ogan Ilir associated with understanding (the concept of balanced nutrition, quantity of feeding practices in terms, frequency, form, variety, and type of food). This study used a qualitative approach. The data collection technique is Focus Group Discussion. Data processing was done manually using the content analysis method (analysis).

Results: The results showed majority of mothers do not understand that concept of balanced nutrition, for this aspect the number of feeding infants in Ogan Ilir still do not meet the nutritional needs to children as seen from the children often do not prepare food to consume by their mother if the child does not as the dishes served. From the aspect of the frequency, almost mothers only give meal 2-3 times and one times an additional food during the day. From this aspect of a mother, a form has given the same food with family to meal, but this menu gives only food in like a child. In terms of variety of food provided to children are still less, and most children do not consume vegetables and fruit.

Conclusions: Mother feeding patterns in children are not good, lack of parental support in providing food resulted in children accustomed to eating that is not good. Appropriate educational media is the required age of children to increase the child's knowledge about nutritious food and motivate children to want to eat nutritious food.
\end{abstract}

Keywords: Mother, feeding pattern, child feeding, balanced nutrition

\section{MENJELAJAHI PRAKTEK PEMBERIAN KESEHATAN IBU DARI ANAK, USIA 4-6 TAHUN: STUDI KUALITATIF}

\begin{abstract}
ABSTRAK
Latar belakang: Memberi makan atau pola asuh yang baik yang mempengaruhi pertumbuhan dan kecerdasan anak. Untuk itu, perlu pola makan atau pola asuh makan yang benar dan seimbang agar tetap sehat dan terhindar dari infeksi atau penyakit lain yang berkaitan dengan gizi. Diet seimbang adalah makan sesuai dengan komposisi makanan yang dibutuhkan tubuh kita dalam porsi yang disesuaikan dengan kebutuhan anak-anak di setiap usia.

Metode: Responden dalam penelitian ini adalah orang tua dari anak-anak TK Rabbani Indaralaya Utara dengan kisaran usia 4-6 tahun. Implementasi FGD dihadiri oleh 12 orang, terdiri dari; tiga peneliti, dua menit, dan tujuh responden. Responden dipilih melalui purposive sampling, berdasarkan kriteria yang telah ditentukan dan dianggap mampu menjawab masalah penelitian. Tujuan dari penelitian ini adalah untuk mengeksplorasi lebih dalam tentang pengasuhan ibu menyusui di Ogan Ilir terkait dengan pemahaman (konsep gizi seimbang, jumlah praktik pemberian makan dalam hal, frekuensi, bentuk, variasi, dan jenis makanan). Penelitian ini menggunakan pendekatan kualitatif. Teknik pengumpulan data adalah Focus Group Discussion. Pemrosesan data dilakukan secara manual menggunakan metode analisis konten (analisis isi).

Hasil: Hasil penelitian menunjukkan mayoritas ibu tidak memahami konsep gizi seimbang, untuk aspek ini jumlah pemberian makan bayi di Ogan Ilir masih belum memenuhi kebutuhan gizi anak karena dilihat dari anak sering tidak menyiapkan makanan untuk dikonsumsi oleh ibu mereka jika anak tidak seperti hidangan yang disajikan. Dari segi frekuensi, hampir ibu hanya memberi makan 2-3 kali dan satu kali tambahan
\end{abstract}

\footnotetext{
${ }^{1}$ Correspondence Address: Anita Rahmiwati, Faculty of Public Health, Sriwijaya University, Jl. Raya Palembang-Prabumilih km. 32, Indralaya, Kabupaten Ogan Ilir, Sumatera Selatan email : anitafkmunsei@mail.com
} 
makanan di siang hari. Dari aspek seorang ibu, bentuk telah memberikan makanan yang sama dengan keluarga untuk makan, tetapi menu ini hanya memberikan makanan seperti anak kecil. Dari segi variasi makanan yang diberikan kepada anak-anak masih kurang, dan kebanyakan anak tidak mengkonsumsi sayur dan buah.

Kesimpulan: Pola makan ibu pada anak tidak baik, kurangnya dukungan orang tua dalam menyediakan makanan mengakibatkan anak terbiasa makan yang tidak baik. Media pendidikan yang tepat adalah usia yang dibutuhkan anak-anak untuk menambah pengetahuan anak tentang makanan bergizi dan memotivasi anak untuk mau makan makanan bergizi.

Kata kunci: Ibu, pola makan, pemberian makan anak, gizi seimbang

\section{INTRODUCTION}

Children will grow according to age, but some things can affect the growth that can lead to disruption in growth. According to data from the WHO in 2016, the number of stunted children has increased at an alarming rate in West and Central Africa -from 22.9 million to 28.1 million. At the same time, the prevalence of children was wasted of $7.7 \%$ and severely wasted $2.5 \%$. At $16 \%$ of South Asia's wasting prevalence represents a 'critical' public health problem including Indonesia. Indonesia in 2014 is included in the state with high malnutrition as much as $12 \%$ of children under five years of age. Almost two out of every three children in rural areas in Indonesia are anemic. ${ }^{1}$ Therefore, feeding the child should be taken to ensure that children do not lack nutrients that can cause problems growth of children.

The nutritional status is determined by food consumption that is given to a child, ${ }^{\text {two }}$ proper feeding in children may influence weight gain optimally so that the child can experience growth and progress with healthy and tasty. Child's diet plays an essential role in the growth and development of children and can help to the intelligence of children because of foods there are nutrients that the body needs children not the deficiency of nutrients that can cause infectious diseases, absolute child. Improper feeding can cause children are malnourished, poor nutrition, intelligence is not the maximum, lowered immune system and stunted growth and development. ${ }^{1}$ For that, it is necessary for feeding patterns or parenting eat right and balanced in order to stay healthy and avoid infection or other diseases related to nutrition. A balanced diet is eating appropriate food composition body needs portion adapted to children at each age. ${ }^{3}$

Complementary feeding is too early or late is a common problem that often occurs in the community. Provision of food variation in children is needed because children need a different nutritional intake. In addition to improper practices in feeding, people's habits are also very influential. As for the things to be considered in the feeding of children that includes the age of the child, the frequency of feeding in a day, the amount of feeding or portion for one meal, the texture of food, the variety of food, provide food actively/responsive in children and always keep clean. ${ }^{4}$ Feeding practices were less precise always meet the child's willingness to food consumed that he wants, even coercing the child to want to eat certain foods.

Feeding practices for children there is an unknown factor that may affect such economic factors which factor this relates to income and price where if rising incomes will increase odds that purchasing power of families to buy food for the children. ${ }^{5}$ Social and cultural factors are associated with feeding practices for children in which these factors can affect mother to determines what foods to consume her and also to see the processing, preparation, and presentation of food to whom and under what conditions food is managed. ${ }^{6}$

From the results of the study it is known that the practice of feeding a toddler in the urban village of Semarang most of $53.7 \%$ is not good, and $46.3 \%$ of proper feeding. There are $36.4 \%$ of under-fives with good 
nutritional status, $53.5 \%$ have less nutritional status, and $12.1 \%$ have malnutrition status. While according to research conducted by ${ }^{4}$ on the analysis of feeding practice relationship with nutritional status of children aged 3-5 years in pos nutrition village that the majority of parents are less than optimal in feeding for their children, as many as 45 respondents or $58.4 \% .^{7}$ This is not in line with another research, a total of $60.6 \%$ mother's practice are good and $39.4 \%$ unfavorable.

The objective of this study is to explore more deeply about parenting feeding mothers in Ogan Ilir associated with understanding (the concept of balanced nutrition, quantity of feeding practices in terms, frequency, form, variety, and type of food).

\section{METHODS}

This study is qualitative research with a focus to group method. Qualitative Research is used to uncover trends in thought and opinions, and dive deeper into the problem. Respondents in this study are the parents of kindergarten children Rabbani North Indaralaya with a range of aged 4-6 years. Implementation of FGD was attended by 12 people, consisting; three researchers, two secretaries, and seven respondents. Respondents selected through purposive sampling, based on predetermined criteria and is considered capable of answering research problems. FGD class performed a circle with a discussion in the form with a research question, and knowledge about feeding practices and nutrition. Validating results using triangulation respondent sources with different parents of kindergarten children and triangulation theory with another result of research. Triangulation theory is used to comparing the thesis statement with the relevant theoretical perspective to avoid the individual bias of the researcher on the findings or the resulting conclusions. Besides, triangulation theory can improve the depth of understanding of the results of data analysis has been obtained. Data processing was done manually using content analysis.

\section{RESULTS}

Results of interviews conducted on parents of students regarding knowledge about nutrition and feeding practices are quite varied. Most parents have given the same meal with their family meal. Parents are wellinformed about nutritious food as well as good in consumption by children. Some mothers stated that give food to children should be varied. However, some mother is stating that she given food to children should not be varied but this food that like my kids or that children prefer. The interviews were conducted on parents of students as follows:

"Our children receive food that prepared at home?"

"My children do not like to eat vegetables, and just like some vegetables such as potatoes, carrots, spinach, kale."

"If my children do not like to eat rice. More likely to eat vegetables with a little rice. Kids love all kinds of vegetables, especially boiled, but the child is difficult to consumption rice".

"Kids are not like carrots and potatoes. They are want to eat noodles".

Based on the above results illustrate that most children are not receiving particular food. Also, children tend to eat a meal in the preferred course. Strengthened also in the following interview:

"What your kids want several foods that should be there every day?"

"Yes, there is - chicken eggs. Every day should be a chicken egg. But not every meal. If you already eat eggs in the morning, afternoon or evening her another meal. What is important in a day should eat eggs".

The results of the above interviews illustrate that granting of a varied diet is still darting less. Parents need to get children to eat all types of food. The habit of eating foods that monotonous course can disrupt the status of child nutrition. To meet the nutritional 
adequacy of parents would try to convince his son to want to consume. In this study illustrates some of the efforts made by parents to meet the nutritional needs of children who refuse certain foods.

"when the child refuses food delivered, what did you do?"

"if my child does not want to eat out, his usual I mixed knew her with eggs and vegetables like carrots and sprouts."

"If I usually change with food the other, my son likes his soy steak, so I change out of her with soy steak

"forced a little, ask the children prefer food "giving supplements vegetables."

"How many time mothers give feed to children?

"The day usually eat rice 2-3 times. However, if the morning often does not want breakfast. Each usually meals only one scoop of rice, but it depends on the willingness of children. If you want a lot more. Sometimes one ladle is not in spending. If they did not eat, I give them additional food like bread".

The results showed that feeding practices in children are still not right. Parents prefer their willingness compared with the nutritional needs that must be met for a child in the future growth and development. In terms of frequency of feeding in children, most mothers gave the main food two times and one time for a snack. However, some children did not waste food. Of course, it will disturb in the fulfillment of nutrients. Nutrients needed for school children that are high in nutrients to support growth and development, energy thinking, physical activity, and endurance. Children do not just need carbohydrates and protein only proper nutrients all macro-nutrients such as carbohydrates, fats, proteins, and micro nutrients such as vitamins and minerals are also needed.

If the mother was at work preparing meals to keep mothers and some are preparing or giving food to my grandmother, most of them do not have a nanny. In the provision of food for the main meals 2-3 times a day and there is also a child that does not want the morning breakfast and for a snack or snacks only occasionally because they eat rice immediately after school and do not want to eat rice although they drink milk and eat bread.

"who is prepare food for your children?"

"mother, grandmother., not a caregiver."

"how many time you prepare the main meal a day?"

"2-3 times. If you want not to breakfast in the morning."

"How many times give a snack?"

"Sometimes. Home school directly eat rice.

Do not like to eat rice at all; only drink milk, bread".

Results of interviews conducted most moms know that nutritious food for her children. The following interview:

"According to the mother eating good and not good for any child?"

"it is a good food sample such as rice, vegetables, eggs, soy steak, fruit, and milk. If it is not good eating street food like a snack, instant noodles. However, children like to eat instant noodles, so I love noodles".

The parents basically can distinguish the food was good and not good for the consumer, but in her practice, her parents have not done well. Most kids who do not want to eat food prepared like vegetable mothers, for example, they do not like children prefer to eat instant noodles. If every mother prepared food, they do not like the mother does not give instant noodles.

Children who are voters on specific eating will affect their nutritional status. In this study proved that there are still some parents who do not understand the varied diet that has good nutritional value for consumption. However, there are also parents who understand nutritious food but does not apply in the practice of feeding their children. Several reasons make the parents do not apply the provision of good food for their children, 
while the reasons parents do not provide good food depicted in the following interview:

"My child wants not to eat the food because it is not like the food. Sometimes they are always playing and forget to eat. Also, the kids would rather snack than to eat food prepared at home".

The results indicate that the mother let the eating problems in children. Parents make an effort in feeding the children and get children to buy a snack from the give food cooked at home.

At the time of feeding to the child's mother often fed while playing than telling them to feed themselves, because if they eat themselves sometimes, rice prepared not they spend if fed especially while they are again playing their eating more.

"What is the granting of the food like?

"Bribe. Sometimes when eating alone is not exhausted. If I was bribing, they are can eating more, while playing".

\section{DISCUSSION}

Every child has a different diet. $^{8}$ Of course, this is caused by the parent's ability when feeding. Children need to embedded on a good diet early as the importance of eating fruits and vegetables, eating foods that are diverse and eat with ample servings, because school-age children is the best time to practice eating behaviors, ${ }^{9}$ When children know the knowledge about the benefits of vegetable consumption of children will unconsciously attract to eating these foods. Introducing vegetables and other foods repeatedly and continuously in children will be able to increase the child's interest in these foods.

The work done by parents in providing food to children is different. Eating habits in the considerable family influence on the diet of children, children like and dislike several foods formed from the family diet. The results showed majority of mothers do not understand that concept of balanced nutrition, for this aspect the number of feeding infants in Ogan Ilir still do not meet the nutritional needs to children as seen from the children often do not prepared food to consume by their mother if the child does not like the dishes being served. ${ }^{10}$ Therefore parents must pay attention to diet their children, parents should be able to control the food was excellent and not right for her child. ${ }^{11}$ Factors that affect the nutritional status of children is nutrition and parenting in feeding. Success or failure lies child nutrition in the mother. ${ }^{12}$ Good child's diet depends on the mother's knowledge and skills in preparing nutritious food menu.

From the aspect of the frequency almost mothers only give meal 2-3 times and 1 times a additional food during the day. From this aspect of mother form has given the same food with family to meal but this menu give only food in like a child. In terms of variety of food provided to children are still less, and most children do not consume vegetables and fruit. ${ }^{13}$ As we know that in the day of his ideal main food given three times and the food snacks two times. Poor eating habits plus the tendency of children who do not want to eat vegetables can affect the nutritional status of children. ${ }^{14}$ Therefore, parents need to take action that makes kids want to eat nutritious foods, especially fruits and vegetables because of the nutrients contained therein are beneficial to health and can increase endurance and prevent infectious diseases.

Feeding pattern or proper eating habits can improve the nutritional status of children conversely if the pattern or improper eating habits can lower the nutritional status of children. Results were confirmed by ${ }^{15}$ found that balanced eating habits related to the nutritional status of children. Good eating habits need to be practiced from an early age through the provision of a varied diet and to teach children to eat at the right time.

Feeding patterns made by the parents based on a schedule of food, type of food, as well as portions of the right foods can affect the normal nutritional status. Conversely, if the feeding pattern that is not by the schedule, the number and types will result in the child being thin or having a healthy nutritional status. The results showed that mother feeding patterns in children is not good, lack of parental support in providing food resulted in children accustomed to eating that is not good. Parents need to emphasize the feeding patterns in children according to choose foods that contain balanced nutrition. ${ }^{16}$ If compliance is achieved with proper nutrients, 
the nutritional status of children will be functional.

Fulfillment of the balanced nutrients derived from food varied, not only from one type of food. Each type of foods contain different nutrients and have different functions for the body. Materials balanced diet clearly illustrated in the food pyramid.

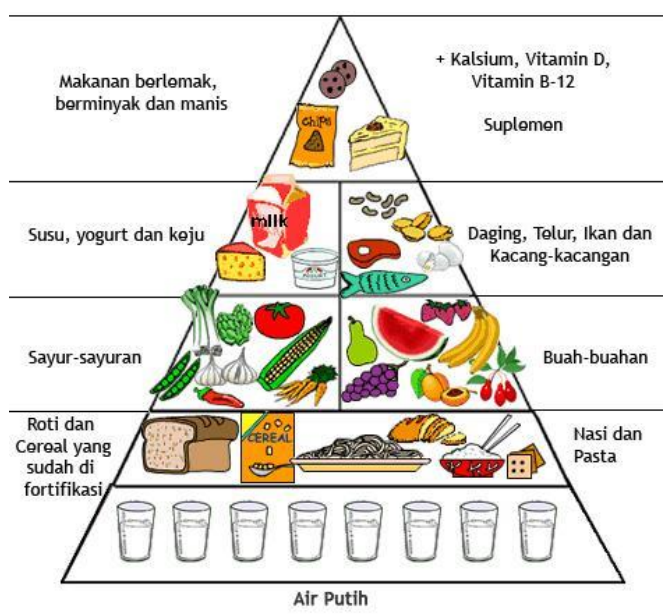

Picture. 1.1.

Balanced food pattern "Food Pyramid." Source: "Towards Healthy Living Balanced Nutrition for Toddlers". ${ }^{9}$

The first food pyramid that is the source of energy substances (carbohydrates) such as rice, bread, potatoes, and others. Second, foods containing regulators (vitamins and minerals) that vegetables and fruits. Third, foods that contain builder substances (proteins) derived from animal and vegetable such as eggs, meat, fish, tofu, soy steak, and others.

Presentation of food for children requires creativity mother for food looks appealing to cause the child's appetite. The presentation of the food that will be given to the child should pay attention to the portion or measure the consumption of meals and meal frequency are recommended in a day. Feeding is divided into three meals that morning at 07:00 to $08: 00,12: 00$ to $13: 00$ o'clock noon on the day and evening at 18:00 to $19: 00 .{ }^{9}$ Giving snack between meals that is at 10:00 to 11:00 and at 4:00 p.m. to 5:00 p.m.

Provision of information about the practice of feeding by mothers to children of school age is essential to do, either by extension or using media such as leaflet or poster with a message that is easily understood by the parents through guidance by health care workers and people who are there in the surrounding neighborhood. Given the nutritional needs of school children is essential for growth, parents, especially mothers have a role in regulating the diet of children. The provision of nutritious food is closely related to durability as well as a child's learning ability.

Energy intake is useful in metabolic processes in the energy to the body. Give nutrition is used for activities and form the structure of organs and cell division. When energy intake is less, then it will disrupt cell division. Nutritional deficiencies cause children susceptible to infectious diseases, as well as affect the child's appetite. If the child's diet is not done correctly, it can interfere with the growth and development of children. ${ }^{1}$ Children will be thin and can cause children are malnourished.

\section{CONCLUSION}

The pattern of feeding by the mother on the child is still not good, because the mother's lack of knowledge about nutrients in foods with a tendency. The child who refuses to eat, and just like certain foods and children often do not consume food prepared by the mother. Lack of parental support in providing food resulted in children accustomed to eating that is not good. Parents prefer their willingness compared with the nutritional needs that must be met. In terms of frequency of feeding in children, most mothers gave the main food two times and one times the food snacks. Need appropriate educational media appropriate age of children to increase the child's knowledge about nutritious food and motivate children to want to eat nutritiously.

\section{LIMITATION}

The limitation of this research is that the location of the research is not conducive because many children are hanging around so that respondents do not focus on the interview. 


\section{REFERENCES}

1. Purwani, E., and Mariyam. Feeding Patterns with Nutritional Status of Children Aged 1 To 5 Years in Kabunan Parks Pemalang. Journal of Child Nursing. 2013.

2. Wahyuni S. and Wahyuningsih A. Feeding Practice on Baby and Children with Heavy Weight Influence in District of Klaten. Journal of Midwifery, Stikes Muhammadiyah Klaten. 2016: 349-254

3. Silawati. Et al. Feeding Practice for Infants and Children in Disaster Situations. Jakarta: Ministry of Communication World Vision Indonesia. 2016Suryani ID. And Andrian DR. Relationships Genesis Practice Feeding With Less Weight In Children Aged 6-24 Months in Puskesmas Sidoarjo. Journal of Health Airlangga University. 2015.

4. Perdani, ZP. Et al. Relations Feeding Practices with Nutritional Status of Children Aged 3-5 Years in Tegal Kunir Hearth Lor Mauk. Journal of Muhammadiyah University Tangerang. 2016.

5. Suryani ID. and Andrian DR. Relationships Genesis Practice Feeding With Less Weight In Children Aged 624 Months in Puskesmas Sidoarjo. Journal of Health Airlangga University. 2015.

6. Lestari TW. Et al. The Effect of Toddler Feeding Practice and Mother Knowledge of Nutrition Status in the Vulnerability Meteseh City of Semarang. Journal of Nursing, Poltekkes Kemenkes Semarang. 2013.

7. Pratiwi FA. Et al. Relationship between Mother's Attitude and Practice During Supplementary Feeding's programme toward nutritional status of the children under five years old in sidoharjo local government Clinic of Sragen Region. Journal of Public Health Faculty, University of Muhammadiyah Surakarta. 2015.

8. Droog SM. Et al. Enhancing Children's Vegetable Consumption Using
Vegetable-Promoting Picture Books, the Impact of Interactive Shared Reading and Character-Product Congruence. Journal Appetite. 2013: 73 (2014)73-80.

9. Fibrihirzani H. Relationship between Individual Characteristics, Parents and Environment with Fruit and Vegetable Consumption in Elementary School Students Beji Depok 5 and 7 in 2012. Thesis Faculty of Public Health, University of Indonesia, Jakarta. 2012.

10. Khomsan A. Food and Nutrition for Health. Publisher: Gramedia Pustaka Utama (GPU). 2010.

11. Unicef. The State of the World's Children. Oxford University Press. 1998.

12. Suhardjo. Food and Nutrition Plan. Jakarta: Earth Literacy. 2003.

13. $\mathrm{MOH}$, Guidelines for Nutrient Consumption Monitoring. Jakarta. 2006. Retrieved on 19 September 2017. Available from: http://www.depkes.com.

14. Kusumo. RA Vegetables + Fruits $=$ Healthy; Getting to know the content and Usefulness For Maintaining Healthy Body. Pioneer Media. Yogyakarta. 2010.

15. Silawati. Et al. Feeding Practice for Infants and Children in Disaster Situations. Jakarta: Ministry of Communication World Vision Indonesia. 2016.

16. Tella AC. The Relationship of Diet with Nutritional Status in Toddlers in the Working Area of Community Health Centers Paniki Mapanget Districts. Manado: Nursing Science Program Faculty of Medicine, University of Sam Ratulangi. 2012.

17. Lestari TW. Et al. The Effect of Toddler Feeding Practice and Mother Knowledge of Nutrition Status in Vulnerability Meteseh City of Semarang. Journal of Nursing, Poltekkes Kemenkes Semarang. 2013.

18. Subarkah, et al. Feeding Patterns Against Increased Nutritional Status in 
Children after 1-3 years. Nurses Education Studies Program Faculty of

Nursing, University of Airlangga. 2016 